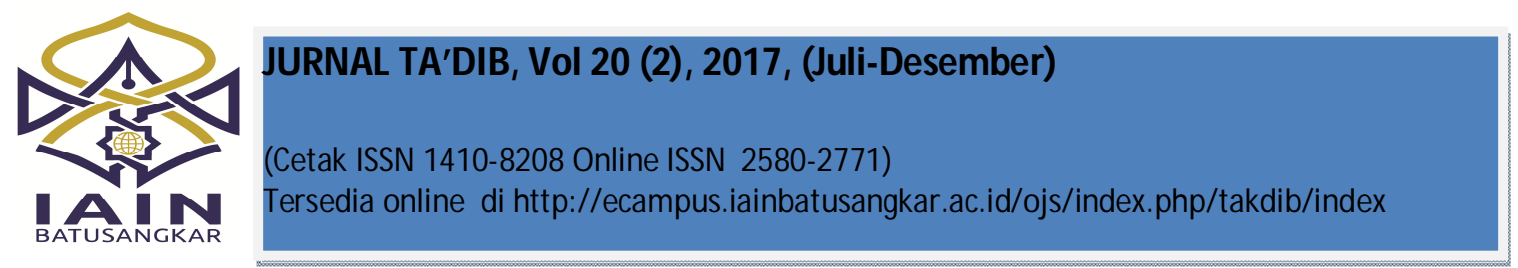

\title{
ENHANCING STUDENTS'MATH LEARNING OUTCOMES ON DETERMINING MULTIPLICATION OPERATION MATERIAL THROUGH NUMBERED HEAD TOGETHER (NHT) MODEL
}

\author{
Yenita*) \\ Dinas Pendidikan dan Kebudayaan \\ Kabupaten Tanah Datar Guru Kelas SDN \\ 04 Koto Gadang Kecamatan Padang \\ Ganting, Sumatera Barat, Indonesia \\ E-mail: yenita.yen31@gmail.com
}

Abstract: This study aims at describing the use of multiplication operations through number head together strategy in improving mathematics learning outcomes. This is a classroom action research using qualitative and quantitative data. The research procedures are: planning stage, implementation stage, observation stage, and reflection stage. The data were obtained through writing test and observation sheet. The subjects of the study were the fourth graders of SD 04 Koto Gadang Kec. Padang Ganting, Tanah Datar regency, the academic year 2015/2016. The results shows that in Cycle I, the determining multiplication operations through cooperative learning type Numbered Heads Together (NHT) can improve $71 \%$ of students' math learning outcome. Besides, based on the observation result, it is found that the teacher activity in teaching cycle I was $74 \%$ accomplished, and the student activity $77 \%$ of the average meeting I and II. Moreover, in Cycle II, students' activities increased to be $89 \%$, and the students' to be $92 \%$ of average meeting I and II. It is summarized that cooperative learning type Numbered Heads Together (NHT) can improve the students' mathematics learning outcomes on the determining multiplication operation materials in Class IV SDN 04 Koto Gadang Padang Ganting Subdistrict Tanah Datar

Key words: Learning outcomes, Numbered Head Together (NHT) Model, Cooperative Learning.

Dalam menanamkan konsep

\section{PENDAHULUAN}

Matematika merupakan salah satu mata pelajaran yang diajarkan di semua jenjang pendidikan yang memliki peran yang sangat penting dalam penguasaan ilmu pengetahuan dan teknologi. Pembelajaran matematika di Sekolah Dasar (SD) perlu mendapat perhatian yang serius dari berbagai pihak seperti pendidik, pemerintah, orang tua, maupun masyarakat, karena pembelajaran matematika di sekolah dasar merupakan peletak konsep dasar yang dijadikan landasan untuk belajar pada jenjang berikutnya. Selain itu penguasaan matematika yang kuat sejak dini diperlukan untuk penguasaan dan penciptaan teknologi di masa depan. matematika kepada siswa sejak dini sangatlah perlu adanya proses pembelajaran yang baik dan mampu melatih siswa dalam kegiatan pembelajaran matematika tersebut. Permendiknas RI No. 41 (2007:1) secara tegas mengamanatkan bahwa, "proses pembelajaran pada setiap satuan pendidikan dasar dan menengah harus interaktif, inspiratif, menyenangkan, menantang, dan memotivasi siswa untuk berpartisipasi aktif serta memberikan ruang yang cukup bagi prakarsa, kreativitas dan kemandirian sesuai dengan bakat, minat, dan perkembangan fisik serta psikologis siswa". Hal ini menunjukkan bahwa dalam pembelajaran matematika sejatinya dimulai dengan pengenalan 
masalah yang sesuai dengan kehidupan sehari-hari dan sekaligus melibatkan peran aktif siswa dalam proses pembelajarannya.

Untuk mencapai hal tersebut guru perlu merancang pembelajaran yang sesuai dengan tujuan pembelajaran matematika yang akan dicapai dalam proses pembelajaran. dalam menciptakan proses pembelajaran yang baik perlu adanya guru yang profesional di bidangnya. Guru profesional pada dasarnya mampu menyampaikan materi pembelajaran secara tepat sesuai dengan kebutuhan siswanya. Untuk mencapai hal tersebut seorang guru harus memiliki kemampuan menciptakan pembelajaran yang efektif, kreatif dan menyenangkan kepada siswa. Salah satunya guru harus mampu memnggunakan model dan pendekatan pembelajaran yang tepat sesuai dengan karateristik mata pelajaran dan siswa sehingga tujuan pembelajaran matematika dapat tercapai.

Berdasarkan pengalaman peneliti, sebagian siswa kelas IV SDN 04 Koto Gadang Kecamatan Padang Ganting Kabupaten Tanah Datar belum memperlihatkan minat yang bagus pada pelajaran matematika. Hal ini terbukti pada hasil belajar siswa pada tahun 2015 pada materi menentukan operasi perkalian, yang menyatakan bahwa nilai tertinggi pada ulang harian pada semester sebelumnya hanya 80 pada pembelajaran matematika, nilai terendahnya adalah 32 , sedangkan rata-ratanya adalah 51,81. Hasil itu menunjukkan katagori sedang yang tentunya belum memenuhi standar keberhasilan yang telah ditetapkan yaitu 70. Pada umumnya para siswa menganggap bahwa matematika merupakan pelajaran yang sulit dipahami sehingga tidak sedikit siswa yang takut terhadap mata pelajaran matematika. Dalam pembelajaran siswa kurang aktif dan kurang tertantang pada materi menentukan operasi perkalian. Salah satu penyebabnya penggunaan metode guru yang kurang tepat dalam pembelajaran matematika pada materi menentukan operasi perkalian.

Hal tersebut mengakibatkan hasil belajar matematika siswa rendah. Selain itu proses belajar mengajar selama ini masih menggunakan sistem belajar yang berpusat pada guru (teacher centered) dengan menggunakan metode ceramah dan pendekatan yang dipakai masih tekstual semua itu harus berubah dan diikuti oleh guru yang bertanggung jawab atas penyelenggara pembelajaran di sekolah. Salah satu perubahan tersebut adalah orientasi pembelajaran yang berpusat kepada guru (teacher centered) beralih berpusat kepada siswa (student centered), metodologi yang semula didominasi ekspositori berubah ke partisipatori dan pendekatan yang semula tekstual berganti menjadi kontekstual. Semua perubahan itu dimaksudkan untuk memperbaiki mutu pendidikan, baik dalam segi proses maupun pendidikan.

Sementara itu kurikulum yang berlaku saat ini, berpedoman pada Kurikulum Tingkat Satuan Pendidikan (KTSP) yang mengacu kepada Badan Standar Nasional Pendidikan (BSNP). KTSP merupakan upaya untuk menyempurnakan kurikulum agar lebih familier dengan guru, karena mereka banyak dilibatkan dan diharapkan memiliki tanggung jawab yang memadai. Dalam KTSP kiprah guru lebih dominan lagi, terutama dalam penjabaran standar kompetensi dan kompetensi dasar, tidak saja dalam program tertulis tetapi juga dalam pembelajaran nyata di kelas.

Untuk mengatasi masalah yang terjadi pada pembelajaran metematika pada materi menentukan operasi perkalian guru mencoba menggunakan model pembelajaran Numbered Heads Together merupakan tipe pembelajaran kooperatif yang didasari oleh falasafah homo homini socius dimana manusia merupakan mahluk sosial yang tidak bisa hidup sendiri tanpa bantuan orang lain, serta sifat saling ketergantungan manusia dalam memahami hidup. Hal ini berarti kerja sama 
merupakan kebutuhan sangat penting bagi kelangsungan proses belajar.

Menurut Anita Lie (2007: 31) model pembelajaran Numbered Heads Together merupakan model pembelajaran yang efektif untuk meningkatkan ketergantungan positif, interaksi tatap muka, tanggung jawab perorangan, ketrampilan kelompik dan ketrampilan sosial, serta evaluasi. Dengan menerapkan model pembelajaran Numbered Heads Together siswa diharapkan tidak hanya mampu dalam kecakapan akademik saja, tetapi juga dalam kecakapan sosial. Proses pembelajaran yang berlangsung dapat memenuhi tuntutan kurikulum yang berorientasi pada kompetensi dan life skill, sehingga potensi dan kompetensi siswa yang selama ini terpendam dapat berkembang secara optimal sehingga tujuan yang dicita-citakan dapat tercapai.

\section{KAJIAN TEORI Hasil Belajar}

Sudjana (2005: 5) menyatakan bahwa hasil belajar siswa pada hakikatnya adalah perubahan tingkah laku dan sebagai umpan balik dalam upaya memperbaiki proses belajar mengajar. Tingkah laku sebagai hasil belajar dalam pengertian luas mencakup bidang kognitif, afektif dan psikomotorik.

Tirtonegoro (2001:43) lebih jauh mengemukakan bahwa hasil belajar adalah penilaian hasil usaha kegiatan belajar yang dinyatakan dalam bentuk simbol, angka, huruf maupun kalimat yang dapat mencerminkan hasil yang sudah dicapai oleh setiap siswa dalam periode tertentu. Djamarah (1996:23) mengungkapkan hasil belajar adalah hasil yang diperoleh berupa kesan-kesan yang mengakibatkan perubahan dalam diri individu sebagai hasil dari aktivitas dalam belajar. Bloom dalam Sudjana (2010: 22-31) membagi hasil belajar menjadi tiga ranah, yaitu ranah kognitif, ranah afektif dan ranah psikomotorik.

Dari beberapa pendapat tersebut, dapat disimpulkan bahwa hasil belajar adalah penilaian hasil yang sudah dicapai oleh setiap siswa dalam ranah kognitif, afektif dan psikomotor yang diperoleh sebagai akibat usaha kegiatan belajar dan dinilai dalam periode tertentu. Di antara ketiga ranah tersebut, ranah kognitiflah yang paling banyak dinilai oleh para guru di sekolah karena berkaitan dengan kemampuan para siswa dalam menguasai isi bahan pengajaran.

\section{Pembelajaran Matematika}

Antonius Cahya Prihandoko (2006:

1) mengemukakan matematika merupakan ilmu dasar yang sudah menjadi alat untuk mempelajari ilmu-ilmu lain. Oleh karena itu penguasaan terhadap matematika mutlak diperlukan dan konsep-konsep matematika harus dipahami dengan betul dan benar sejak dini. Hal ini karena konsep-konsep dalam matematika merupakan suatu rangkaian sebab akibat. Suatu konsep disusun berdasarkan konsepkonsep sebelumnya, dan akan menjadi dasar bagi konsep-konsep selanjutnya, sehingga pemahaman yang salah terhadap suatu konsep, akan berakibat pada kesalahan pemahaman terhadap konsepkonsep selanjutnya. Em Zul Fajri (2007: 554) menyatakan pengertian matematika adalah ilmu tentang bilangan-bilangan, hubungan antara bilangan dan prosedur operasional yang digunakan dalam penyelesaian masalah bilangan. Elea Tinggih (dalam Erman Suherman, 2001: 18) mengemukakan berdasarkan etimologis perkataan matematika berarti ilmu pengetahuan yang diperoleh dengan bernalar. Ruseffendi (Sri Subarinah, 2006: 1) mengatakan matematika itu terorganisasikan dari unsur-unsur yang tidak didefinisikan, definisi-definisi, aksioma-aksioma dan dalil-dalil yang dibuktikan kebenarannya sehingga matematika disebut ilmu deduktif.

$\begin{array}{lcrr}\text { Selanjutnya } & \text { (Karso, 2007 } & \text { : } & \text { 1.42) } \\ \text { mengatakan } & \text { Matematika } & \text { adalah } \\ \text { angka\&angka } & \text { perhitungan } & \text { yang } \\ \text { merupakan bagian dari hidup } & \text { manusia. } \\ \text { Matematika } & \text { menolong } & \text { manusia }\end{array}$


memperkirakan secara eksak berbagai ide dan kesimpulan. Matematika adalah pengetahuan atau ilmu mengenai logika dan problem \& problem menarik. Matematika membahas faktor\&faktor dan hubungan \& hubungannya, serta membahas problem ruang dan bentuk.

Berdasarkan uraian-uraian tersebut, dapat ditarik kesimpulan mengenai definisi matematika. Matematika adalah kumpulan ide-ide yang bersifat abstrak, dengan struktur-struktur deduktif, mempunyai peran yang penting dalam pengembangan ilmu-ilmu lain.

\section{Tujuan Pembelajaran Matematika}

Menurut Suharjo (2006:85)

mengemukakan pembelajaran pada hakikatnya tidak hanya sekedar menyampaikan pesan pembelajaran kepada peserta didik, akan tetapi merupakan aktivitas profesional yang menuntut guru untuk dapat menggunakan keterampilan dasar mengajar secara terpadu, serta menciptakan sistem lingkungan yang memungkinkan peserta didik dapat belajar secara efektif dan efisien. Merujuk pada berbagai pendapat para ahli matematika SD dalam mengembangkan kreativitas dan kompetensi siswa, maka guru hendaknya dapat menyajikan pembelajaran yang efektif dan efisien, sesuai dengan kurikulum dan pola pikir siswa.

Dalam mengajarkan matematika, guru harus memahami bahwa kemampuan setiap siswa berbedabeda, serta tidak semua siswa menyenangi mata pelajaran matematika. Pembelajaran matematika yang baik menuntut penggunaan metode ataupun model pembelajaran yang bervariasi. Hal ini masuk akal karena suatu topik matematika kadang-kadang dapat diajarkan secara lebih baik hanya dengan menggunakan metode tertentu. Selain itu jika guru matematika hanya dengan menggunakan satu jenis metode mengajar, maka akan dimungkinkan para siswa menjadi lebih cepat bosan atau jemu terhadap materi yang disampaikan.
Konsep-konsep pada kurikulum matematika SD dapat dibagi menjadi tiga kelompok besar, yaitu penanaman konsep dasar, pemahaman konsep, dan pembinaan keterampilan. Untuk menuju tahap keterampilan tersebut harus melalui langkah-langkah benar yang sesuai dengan kemampuan dan lingkungan siswa, yaitu (1) Penanaman konsep dasar, (2) Pemahaman konsep, dan (3) Pembinaan Keterampilan (Heruman, 2008: 2-3).

Matematika sangat diperlukan dalam kehidupan manusia, maka matematika perlu diajarkan bagi siswa SD. Sesuai dengan kurikulum 2006 KTSP, disebutkan tujuan mata pelajaran matematika di SD adalah:

a. Memahami konsep matematika, menjelaskan keterkaitan antar konsep dan mengaplikasikan konsep atau algoritma secara luwes, akurat, efisien, dan tepat, dalam pemecahan masalah.

b. Menggunakan penalaran pada pola dan sifat, melakukan manipulasi matematika dalam membuat generalisasi, menyusun bukti, atau menjelaskan gagasan dan pernyataan matematika.

c. Memecahkan masalah yang meliputi kemampuan memahami masalah, merancang model matematika, menyelesaikan model dan menafsirkan solusi yang diperoleh.

d. Mengomunikasikan gagasan dengan simbol, tabel, diagram, atau media lain untuk memperjelas keadaan atau masalah.

e. Memiliki sikap menghargai kegunaan matematika dalam kehidupan, yaitu memiliki rasa ingin tahu, perhatian dan minat dalam mempelajari matematika, serta sikap ulet dan percaya diri dalam pemecahan masalah.

Memahami konsep matematika sangatlah penting untuk mengaplikasikannya dalam pemecahan masalah. Maka pada Sekolah Dasar, guru harus menyampaikan konsep matematika dengan baik dan benar agar dapat mengaplikasikan pada kehidupan nyata dengan benar. Selain memahami konsep, 
melatih cara berfikir dan bernalar dalam pembelajaran matematika juga penting untuk memudahkan dalam memecahkan suatu masalah. SD merupakan pondasi pengajaran matematika yang nantinya digunakan untuk melanjutkan ke jenjang yang lebih tinggi. Maka dari itu, memiliki sikap menghargai kegunaan matematika dalam kehidupan harus ditanamkan agar siswa dapat dengan senang hati mempelajari matematika.

Berdasarkan tujuan mata pelajaran matematika tersebut, dapat dimengerti bahwa matematika itu bukan saja dituntut sekedar menghitung, tetapi siswa juga dituntut agar lebih mampu menghadapi berbagai masalah dalam hidup ini. Masalah itu baik mengenai matematika itu sendiri maupun masalah dalam ilmu lain. Maka, pembelajaran matematika di SD perlu dirancang sebaik mungkin agar siswa dapat mencapai tujuan pembelajaran tersebut.

\section{Metode kooperatif tipe Numbered Heads Together (NHT)}

Model Pembelajaran kooperatif tipe Numbered Heads Together (NHT) merupakan salah satu dari beberapa tipe model pembelajaran kooperatif. Pembelajaran kooperatif tipe Numbered Heads Together (NHT) dirancang untuk mempengaruhi pola interaksi siswa dan memiliki tujuan untuk meningkatkan penguasaan akademik. Ibrahim (Rahmi, 2008: 3) menyebutkan bahwa "NHT merupakan variasi dari salah satu metode diskusi kelompok yang lebih banyak meminta keaktifan siswa". Model Pembelajaran kooperatif tipe Numbered Heads Together (NHT) dikembangkan oleh Spencer Kagan pada tahun 1992. Menurut Rahmi (2008: 3) "Ciri khas dari NHT adalah seorang guru hanya menunjuk seorang siswa dengan menyebutkan nomor yang mewakili kelompoknya itu. Sehingga masing-masing anggota kelompok harus paham dengan hasil kerja kelompoknya.

Secara Detail Lie (2008: 59) mengungkapkan: "Model pembelajaran kooperatif tipe Numbered Heads Together (NHT) memberikan kesempatan kepada siswa untuk saling membagikan ide-ide dan mempertimbangkan jawaban yang paling tepat, selain itu model pembelajaran kooperatif tipe Numbered Heads Together (NHT) juga mendorong siswa untuk meningkatkan semangat kerjasama mereka".

Pembelajaran kooperatif NHT memberikan peluang yang besar agarsiswa akan terlibat total dalam pembelajaran, hal inilah yang menjadi alasan dipilihnya NHT (Numbered Head Together)dalam penelitian ini. NHT juga merupakan cara yang sangat baik untuk menambah tanggung jawab individual terhadap diskusi kelompok. Seperti yang diungkapkan oleh Ibrahim (Rahmi, 2008:4): "NHT pada dasarnya merupakan sebuah variasi kelompok, ciri khasnya adalah guru hanya menunjuk seorang siswa yang mewakili kelompoknya tanpa memberitahu terlebih dahulu siapa yang akan mewakili kelompoknya.Cara ini menjamin keterlibatan semua siswa, dan juga merupakan upaya yang sangat baik untuk meningkatkan tanggung jawab individual dalam diskusi kelompok".

Berdasarkan pendapat di atas dapat disimpulkan bahwa pembelajaran kooperatif tipe Numbered Heads Together (NHT) pembelajaran berkelompok yang melibatkan seluruh anggota kelompok untuk memahami materi dan diakhir siswa dituntut memahami materi dengan pemberian kuis berdasarkan nomor masing - masing.

\section{Langkah - Langkah Metode Numbered Heads Together (NHT)}

Pembelajaran kooperatif tipe Numbered Heads Together (NHT) dibagi kedalam empat langkah (Lie, 2008: 60), yaitu:

1. Penomoran (Numbering)

Siswa dibagi kedalam beberapa kelompok, setiap kelompok beranggotakan empat sampai lima orang dan masing-masing 
diberikan nomor sehingga setiap siswa dalam kelompok memiliki nomor yang berbeda sesuai dengan jumlah kelompok dari masingmasing kelompok.

2. Pengajuan pertanyaan (quesioning) Guru mengajukan pertanyaan dan memberikan tugas, kemudian masing-masing kelompok mengerjakannya.

3. Berpikir bersama (Heads Together) Kelompok memutuskan jawaban yang dianggap paling benar dan memastikan setiap anggota kelompok mengetahui jawaban yang telah disepakati oleh semua anggota kelompok.

4. Pemberian jawaban (Answering) Guru memanggil salah satu nomor secara acak. Semua siswa yang memiliki nomor yang disebutkan oleh guru harus bersiap untuk presentasi, karena guru akan memilih satu kelompok yang akan mempresentasikan hasil kerja kelompok secara acak. Siswa dengan nomor dan kelompok yang dipanggil mempresentasikan hasil kerjasama mereka.

\section{METODE PENELITIAN}

Penelitian ini merupakan penelitian tindakan kelas yang dilakukan oleh guru untuk memperbaiki pelajaran matematika pada materi menentukan operasi perkalian di Kelas IV SDN 04 Koto Gadang Kecamatan Padang Ganting Kabupaten Tanah Datar. Kegiatan dilakukan dengan memberikan materi menentukan operasi perkalian dengan menggunakan metode kooperatif tipe Numbered Heads Together (NHT). Prosedur melakukan dalam melakukan penelitian ini pertama rencana kegiatan pembelajaran matematika pada materi menentukan operasi perkalian dengan metode kooperatif tipe Numbered Heads Together (NHT) dengan membuat RPP, soal tes, dan lembaran observasi untuk pengamatan. Setelah semua disiapkan guru mengajar matematika pada materi menentukan operasi perkalian dengan mengunakan metode kooperatif tipe Numbered Heads Together (NHT) dan melakukan penilaian sehingga diperoleh hasil penelitian pada akhir kegiatan. Subjek dalam penelitian ini adalah siswa kelas IV SDN 04 Koto Gadang Kecamatan Padang Ganting Kabupaten Tanah Datar. Indikator keberhasilan pada penelitian ini ditetapkan pada awal pelaksanaan kegiatan yaitu $85 \%$ atau $>85 \%$ siswa tuntas dan siswa aktif maka dikatakan penelitian ini berhasil. Alur yang digunakan pada penelitian kelas ini dengan 4 tahapan, perencanaan, pelaksanaan, observasi dan refleksi.

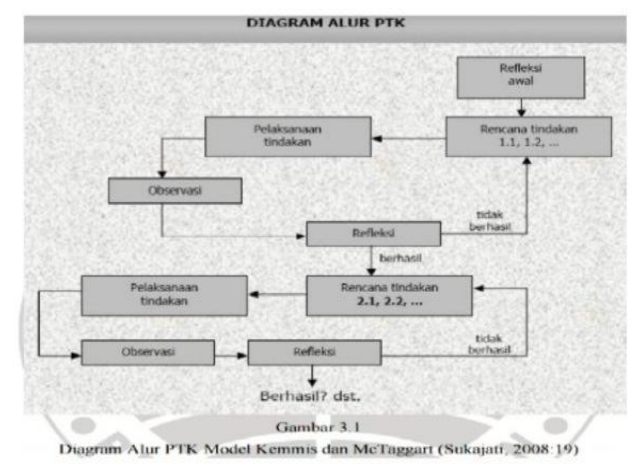

Sumber: Kemmis dan Taggart dalam (Sukajati. 2008:19)

Dalam penelitian ini data diperoleh dari hasil tes tulis dan lebaran observasi guru dan keaktifan siswa dalam belajar dan mengajar dengan metode kooperatif tipe Numbered Heads Together (NHT). Setelah data diperoleh secara keseluruhan data di olah menggunakan rumus yaitu $\frac{F}{N} \times 100$ $\%$.

\section{HASIL DAN PEMBAHASAN Hasil Belajar Siswa}

Setelah dilakukan kegiatan penelitian pada siklus I pertemuan I dan II siswa diberikan tes hasil belajar dari materi pertemuan I dan II siklus I. Hasil belajar matematika pada materi menentukan operasi perkalian melalui metode kooperatif tipe Numbered Heads Together 
(NHT) siklus I pertemuan I dan II sebagai berikut:

Tabel 1: Hasil Belajar Siklus I

\begin{tabular}{|c|c|c|c|}
\hline \multicolumn{2}{|c|}{ Siklus I Pertemuan I } & \multicolumn{2}{c|}{ Siklus I Pertemuan II } \\
\hline Siswa & $\begin{array}{r}\text { Siswa } \\
\text { belum } \\
\text { tuntas }\end{array}$ & $\begin{array}{l}\text { Siswa } \\
\text { tuntas }\end{array}$ & $\begin{array}{r}\text { Siswa } \\
\text { Belum } \\
\text { Tuntas }\end{array}$ \\
\hline $67 \%$ & $33 \%$ & $74 \%$ & $26 \%$ \\
\hline
\end{tabular}

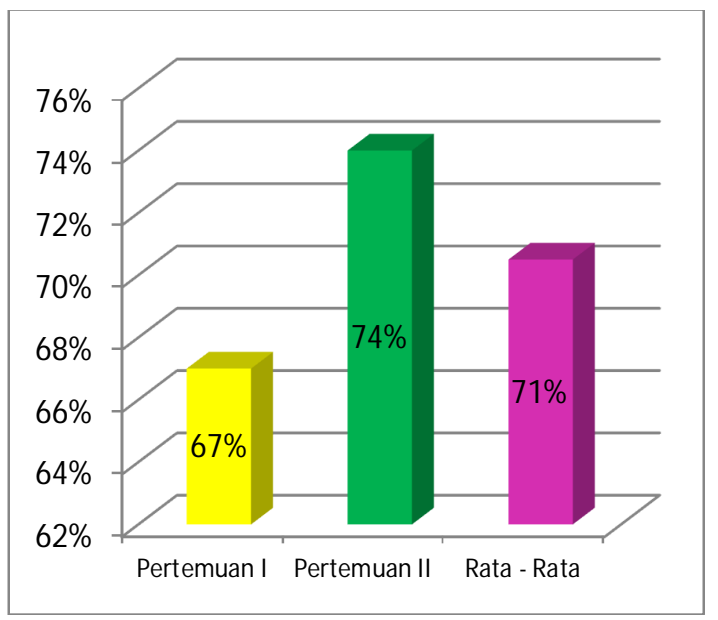

Pada kegiatan pembelajaran dengan dengan metode kooperatif tipe Numbered Heads Together (NHT) hasil belajar matematika pada materi menentukan operasi perkalian ketuntasan siswa dari tes tulis pada siklus I pertemuan I sebanyak $67 \%$ dan pertemuan II $74 \%$. Rata - rata ketuntasan siswa siklus I 71\%. Dari hasil yang peroleh belum memuaskan dan perlu dilakukan reflesi terhadap kelemahan siswa dalam kegiatan pembelajaran.

\section{Aktivitas Guru dan Siswa Siklus I}

Dalam kegiatan pembelajaran aktivitas guru dalam mengajar dan keaktifan siswa dalam belajar dengan metode kooperatif tipe Numbered Heads Together (NHT) diamati oleh observer, adapun hasil pengamatan aktivitas guru dan siswa siklus I sebagai berikut:
Tabel 2: Aktivitas Guru dan Siswa

\begin{tabular}{|c|c|c|l|}
\hline \multirow{2}{*}{ Aktivitas } & \multicolumn{2}{|c|}{ Nilai } & $\begin{array}{l}\text { Rata } \\
\text { Rata }\end{array}$ \\
\hline \multirow{2}{*}{ Aktivitas Guru } & Siklus I P1 & 71 & \multirow{2}{*}{$73 \%$} \\
\cline { 2 - 3 } & Siklus I P2 & 77 & \\
\hline $\begin{array}{c}\text { Keaktifan } \\
\text { Siswa }\end{array}$ & Siklus I P1 & 74 & \multirow{2}{*}{$77 \%$} \\
\cline { 2 - 3 } & Siklus I P2 & 80 & \\
\hline
\end{tabular}

Dari data di atas diperoleh hasil bahwa aktivitas guru dalam matematika dengan menggunakan kooperatif tipe Numbered Heads Together (NHT) kurang terlaksana oleh guru dalam proses pembelajaran pada siklus I pertemuan I rata - rata aktivitas guru dalam melakukan pembelajaran matematika dengan langkah kooperatif tipe Numbered Heads Together (NHT) adalah 25 dari 35 skor maksimal atau $(71 \%)$ terlaksana. Jika dikelompokan 1 aspek berkriteria sangat baik, 3 aspek terlaksana dengan baik dan 2 aspek terlaksana dengan criteria cukup dan 1 aspek berkriteria kurang oleh guru dalam melaksanakan pembelajaran dengan langkah kooperatif tipe Numbered Heads Together (NHT) Pada siklus I pertemuan II rata - rata aktivitas 27 dari 35 (77\%). Jika dikelompokan 1 aspek berkriteria sangat baik, 4 aspek berkriteria baik dan 2 aspek berikriteria cukup. Setelah digabungkan diperoleh nilai aktivitas guru siklus I menjadi $74 \%$ setelah digabungkan pertemuan I dan II. Jika dilihat dari indikator keberhasilan pada penelitian ini yaitu 85 atau $>85 \%$. Maka pada siklus I ini belum berhasil dan perlu dilanjutkan pada siklus II.

Dalam pengamatan aktivitas siswa dalam pembelajaran matematika pada materi menentukan operasi perkalian dengan metode kooperatif tipe Numbered Heads Together (NHT) siklus I pertemuan I rata - rata nilai siswa yang sudah baik dari aspek yang di amati sebanyak 74\% dan siklus I pertemuan II rata - rata siswa yang sudah baik belajar dengan metode kooperatif tipe Numbered Heads Together 
(NHT) sebanyak 80\%. Setelah digabungkan nilai pertemuan I dan II diperoleh aktivitas siswa yang baik pada siklus I yaitu sebanyak $77 \%$ siswa. jika di lihat indikator keberhasilan pada penelitian ini yaitu $85 \%$ atau lebih dari $85 \%$ maka aktivitas siswa perlu diperbaiki pada siklus II dan dilakukan refleksi lagi.

\section{Siklus II}

\section{Hasil Belajar Siswa}

Setelah dilakukan refleksi terhadap kelemahan pada siklus I hasil belajar matematika pada materi menentukan operasi perkalian siswa meningkat pada siklus II ini dengan metode kooperatif tipe Numbered Heads Together (NHT) adapun hasil belajar siswa siklus II sebagai berikut:

Tabel 3 :Hasil Belajar Siklus II

\begin{tabular}{|c|c|c|c|}
\hline \multicolumn{2}{|c|}{ Siklus I Pertemuan I } & \multicolumn{2}{c|}{ Siklus I Pertemuan II } \\
\hline $\begin{array}{c}\text { Siswa } \\
\text { Tuntas }\end{array}$ & $\begin{array}{l}\text { Siswa } \\
\text { belum } \\
\text { tuntas }\end{array}$ & $\begin{array}{c}\text { Siswa } \\
\text { tuntas }\end{array}$ & $\begin{array}{c}\text { Siswa } \\
\text { Belum } \\
\text { Tuntas }\end{array}$ \\
\hline $85 \%$ & $15 \%$ & $93 \%$ & $7 \%$ \\
\hline
\end{tabular}

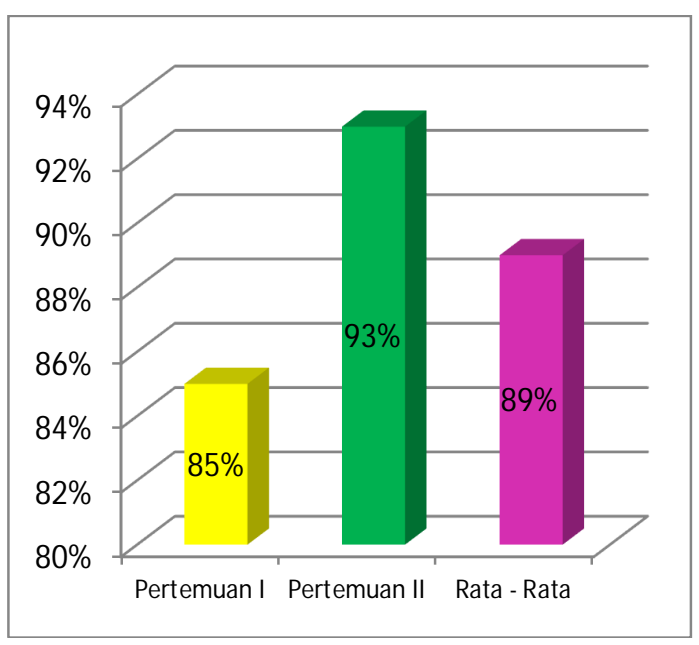

Dari data di atas diperoleh setelah diadakan tes tulis pada siklus II dari materi menentukan operasi perkalian diperoleh nilai rata - rata kelas pada siklus II pertemuan I yaitu 82,4 , dengan ketuntasan siswa sebanyak 23 orang (85\%) dan siswa belum tuntas sebanyak 4 orang (15\%) dari 27 orang siswa. Pada siklus II pertemuan II rata- rata kelas siswa meningkat menjadi 87,6 dan ketuntasan siswa juga meningkat dengan ketuntasan siswa sebanyak 25 orang $(92 \%)$ sedangkan siswa yang belum tuntas hanya 2 orang (7\%) dari 27 orang siswa. Setelah digabungkan ketuntasan pertemuan I dan II diperoleh ketuntasan siswa siklus II yaitu $89 \%$ siswa yang telah tuntas. Pada siklus II ini sudah banyak siswa yang tuntas dalam pembelajaran matematika pada materi menentukan operasi perkalian dari berbagai benda dengan metode kooperatif tipe Numbered Heads Together (NHT). Jika dilihat dari indikator keberhasilan pada penelitian tindakan kelas ini yaitu $85 \%$ atau $>85 \%$ dikatan berhasil, maka penelitian ini sudah berhasil pada siklus II

\section{Aktivitas Guru dan siswa}

Setelah dilakukan refleksi pada siklus I terhadap kelemahan guru dalam mengajar dengan metode kooperatif tipe Numbered Heads Together (NHT) dan keaktifan siswa diperoleh dari hasil pengamatan aktivitas guru dan keaktifan siswa oleh observer, adapun hasil pengamatan aktivitas guru dan keaktifan siswa siklus II sebagai berikut:

Tabel 4 : Aktivitas Guru dan Siswa

\begin{tabular}{|c|c|c|c|}
\hline \multirow{2}{*}{ Aktivitas } & \multicolumn{2}{|c|}{ Nilai } & $\begin{array}{l}\text { Rata }- \\
\text { Rata }\end{array}$ \\
\hline \multirow{2}{*}{$\begin{array}{c}\text { Aktivitas } \\
\text { Guru }\end{array}$} & Siklus II P1 & 88 & \multirow{2}{*}{$93 \%$} \\
\cline { 2 - 3 } & Siklus II P2 & 97 & \\
\hline $\begin{array}{c}\text { Keaktifan } \\
\text { Siswa }\end{array}$ & Siklus II P1 & 88 & \multirow{2}{*}{$92 \%$} \\
\cline { 2 - 3 } & Siklus II P2 & 96 & \\
\hline
\end{tabular}

Tabel diatas memperlihatkan bahwa aktivitas guru dalam pembelajaran matematika dengan menggunakan kooperatif tipe Numbered Heads Together (NHT) kurang terlaksana dalam proses pembelajaran pada siklus II pertemuan I rata - rata aktivitas guru dalam melakukan pembelajaran matematika dengan langkah kooperatif tipe Numbered Heads Together (NHT) adalah 31 dari 35 skor maksimal atau (88\%) terlaksana. Jika dikelompokan 3 aspek berkriteria sangat baik, 4 aspek 
terlaksana dengan baik oleh guru dalam melaksanakan pembelajaran dengan langkah metode kooperatif tipe Numbered Heads Together (NHT) Pada siklus II pertemuan II rata - rata aktivitas 34 dari 35 (97\%). Jika dikelompokan 6 aspek berkriteria sangat baik, 1 aspek berkriteria baik. Setelah digabungkan diperoleh nilai aktivitas guru siklus II menjadi 93\% setelah digabungkan pertemuan I dan II. Jika dilihat dari indikator keberhasilan pada penelitian ini yaitu 85 atau $>85 \%$. Maka pada siklus II ini penelitian ini sudah berhasil jika dilihat indokator keberhasilan penelitian ini $85 \%$ atau lebih.

Dari data diatas diperoleh data bahwa aktivitas siswa dalam belajar pembelajaran matematika pada materi menentukan operasi perkalian dengan metode kooperatif tipe Numbered Heads Together (NHT) sudah terlaksana oleh siswa dalam proses pembelajaran. Pada siklus II pertemuan I aktivitas siswa dalam melakukan pembelajaran I pembelajaran matematika pada materi menentukan operasi perkalian dengan metode kooperatif tipe Numbered Heads Together (NHT) persentase siswa yang aktif sebanayak $88 \%$. Pada siklus II pertemuan II persentase siswa yang aktif sebanyak 96\%. Setelah digabungkan pertemuan I dan II diperoleh aktivitas siswa siklus II yaitu $92 \%$ siswa aktif dalam matematika pada materi menentukan operasi perkalian dengan metode kooperatif tipe Numbered Heads Together (NHT). Jika dilihat dari indikator keberhasilan pada penelitian ini yaitu 85 atau $>85 \%$. Maka pada siklus II ini sudah berhasil.

\section{PEMBAHASAN}

\section{Hasil belajar}

Pembahasan hasil penelitian siklus I meliputi: perencanaan meningkatan hasil belajar matematika pada materi menentukan operasi perkalian dengan metode kooperatif tipe Numbered Heads Together (NHT). Pada kegiatan pembelajaran matematika pada materi menentukan operasi perkalian dengan metode kooperatif tipe Numbered Heads Together (NHT) hasil belajar siswa pada siklus I ketuntasan siswa sebanyak $71 \%$. Pada siklus I ini masih banyak siswa kuarng memahami materi secara baik, salah satu penyebabnya kurang aktifnya siswa dalam belajar baik menganalisis, membuktikan hasil analisis serta menyimpulkan hasil praktikum. Setelah di refeleksi pada siklus I hasil belajar siswa pada pembelajaran matematika pada materi menentukan operasi perkalian dengan metode kooperatif tipe Numbered Heads Together (NHT) ketuntasan siswa meningkat $89 \%$. Pada siklus II ini keaktifan siswa berbeda dengan siklus sebelumnya dimana hampir semua siswa bekerja dengan langkah kegiatan sehingga siswa memilikim pengalaman belajar serta mampu memperoleh pengetahuan dari kegiatan yang dilakukan. Dari siklus I ke siklus II terjadi peningkatan sebesar $18 \%$. Jika dilihat dari indikator keberhasilan pada penelitian ini yaitu $85 \%$ atau $>85 \%$ maka penelitian ini sudah berhasil karena keuntasan siswa melebihi $85 \%$. Untuk lebih rinci persentase peningkatakan siswa yang tuntas dari siklus I ke siklus II lihat grafik di bawah ini

Tabel 5: Peningkatan Hasil Belajar

\begin{tabular}{|c|c|c|c|}
\hline No & Siklus & $\begin{array}{c}\text { Jumlah } \\
\text { Tuntas (org) }\end{array}$ & Ketuntasan \\
\hline 1 & I P1 & 18 & $67 \%$ \\
\hline 2 & I PII & 20 & $74 \%$ \\
\hline 3 & II P1 & 23 & $85 \%$ \\
\hline 4 & II P2 & 25 & $93 \%$ \\
\hline
\end{tabular}

$\mathrm{N}=27$ Orang 


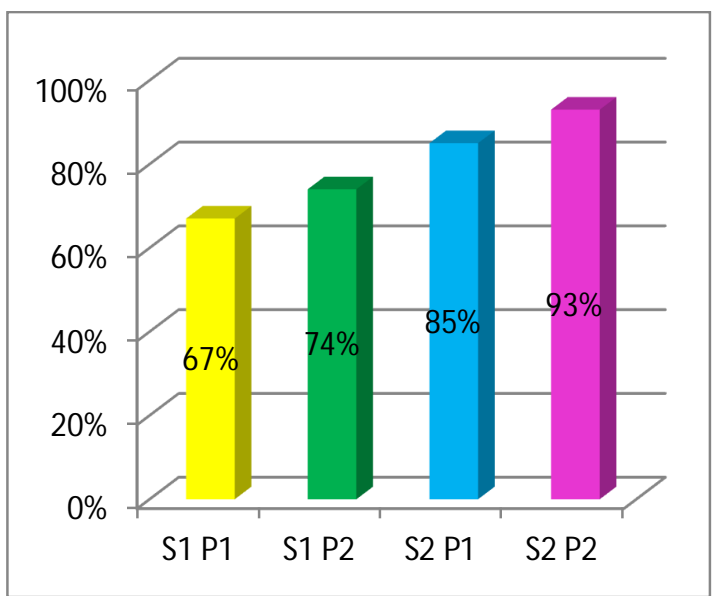

Aktivitas Guru

Kegiatan pembelajaran matematika pada materi menentukan operasi perkalian dengan metode kooperatif tipe Numbered Heads Together (NHT) pada siklus I pertemuan I belum sesuai harapan dengan rata - rata kemampuan guru mengajar dengan metode kooperatif tipe Numbered Heads Together (NHT) pada pembelajaran matematika pada materi menentukan operasi perkalian secara keseluruhan dari semua aspek yang dinilai adalah $74 \%$ terlaksana pada siklus I. Pada siklus I ini masih terlihat guru masih kurang membimbing siswa dalam pembelajaran dan kurang aktif dalam kerja pada kelompoknya. Guru lebih banyak membimbing siswa yang cenderung aktif dalam pembelajaran. Setelah dilakukan refleksi terhadap kelemahan pada siklus I terjadi peningakatan yang signifikan menjadi aktivitas guru melakukan pembelajaran pada pembelajaran matematika pada materi menentukan operasi perkalian dengan metode kooperatif tipe Numbered Heads Together (NHT) pada siklus II meningkat menjadi 93\%. Pada siklus II ini guru terlohat mengajar sesuai dengan langkah pembelajaran yang di rencanakan dan guru mampu membimbing siswa dalam kegiatan pembelajaran. Dari siklus I ke siklus II terjadi peningkatan aktivitas guru sebesar 19\%. Secara keseluruhan pada siklus II ini guru sudah mampu mengajar dengan sangat baik dengan menggunakan metode kooperatif tipe Numbered Heads
Together (NHT) pada pembelajaran matematika pada materi menentukan operasi perkalian. Jika dilihat dari indikator keberhasilan pada penelitian ini yaitu $85 \%$ atau $>85 \%$ maka penelitian ini sudah berhasil karena aktivitas guru dalam mengajar dengan metode kooperatif tipe Numbered Heads Together (NHT) sudah 93\% terlaksana. Untuk lebih jelas lihat tabel peningkatan aktivitas guru pada grafik di bawah ini :

Tabel 6 : Peningkatan Aktivitas Guru

\begin{tabular}{|c|c|c|c|c|}
\hline $\begin{array}{l}\mathrm{N} \\
\mathrm{O}\end{array}$ & Siklus & Pertemuan & Prosentasi & $\begin{array}{c}\text { Rata- } \\
\text { rata } \\
(\%)\end{array}$ \\
\hline 1 & \multirow[b]{2}{*}{ I } & Pertama & 71 & \multirow[t]{2}{*}{$83 \%$} \\
\hline 2 & & Kedua & 77 & \\
\hline 3 & \multirow[b]{2}{*}{ II } & Pertama & 88 & \multirow[t]{2}{*}{$93 \%$} \\
\hline 4 & & Kedua & 97 & \\
\hline & & \multicolumn{2}{|c|}{ Peningkatan } & $19 \%$ \\
\hline \multicolumn{5}{|c|}{$100 \%$} \\
\hline \multicolumn{5}{|c|}{$80 \%$} \\
\hline \multicolumn{5}{|c|}{$70 \%$} \\
\hline \multicolumn{5}{|c|}{$60 \%$} \\
\hline \multicolumn{5}{|c|}{$50 \%$} \\
\hline & & $77 \%$ & & \\
\hline & & & & \\
\hline & & & & \\
\hline & & & & \\
\hline & & S1 P2 & S2 P1 & \\
\hline
\end{tabular}

\section{Aktivitas Siswa}

Pada aktivitas siswa dalam kegiatan pembelajaran matematika pada materi menentukan operasi perkalian dengan metode kooperatif tipe Numbered Heads Together (NHT) pada siklus I rata rata keaktifan siswa dalam pembelajaran yaitu $77 \%$. Pada siklus I ini masih banyak siswa yang kurang aktif dalam pembelajaran baik. Salah satu penyebabnya kurangnya motivasi dari guru dalam mengajar. Setelah di refleksi 
terhadap kekurangan pada siklus I meningkat aktivitas siswa pada pembelajaran matematika pada materi menentukan operasi perkalian dengan metode kooperatif tipe Numbered Heads Together (NHT). Pada siklus II aktivtas siswa meningkat menjadi 92\%. Hampir seluruh siswa aktif dalam kegiatan pembelajaran matematika pada materi menentukan operasi perkalian dengan metode kooperatif tipe Numbered Heads Together (NHT). Pada kegiatan pembelajaran matematika pada materi menentukan operasi perkalian dengan metode kooperatif tipe Numbered Heads Together (NHT) terjadi peningkatan dari siklus I ke siklus II sebesar $15 \%$. Jika dilihat dari indikator keberhasilan pada penelitian ini yaitu $85 \%$ atau $>85 \%$ maka penelitian ini sudah berhasil. Untuk lebih jelas lihat tabel dan grafik di bawah ini.

Tabel 7: Peningkatan Aktivtas Siswa

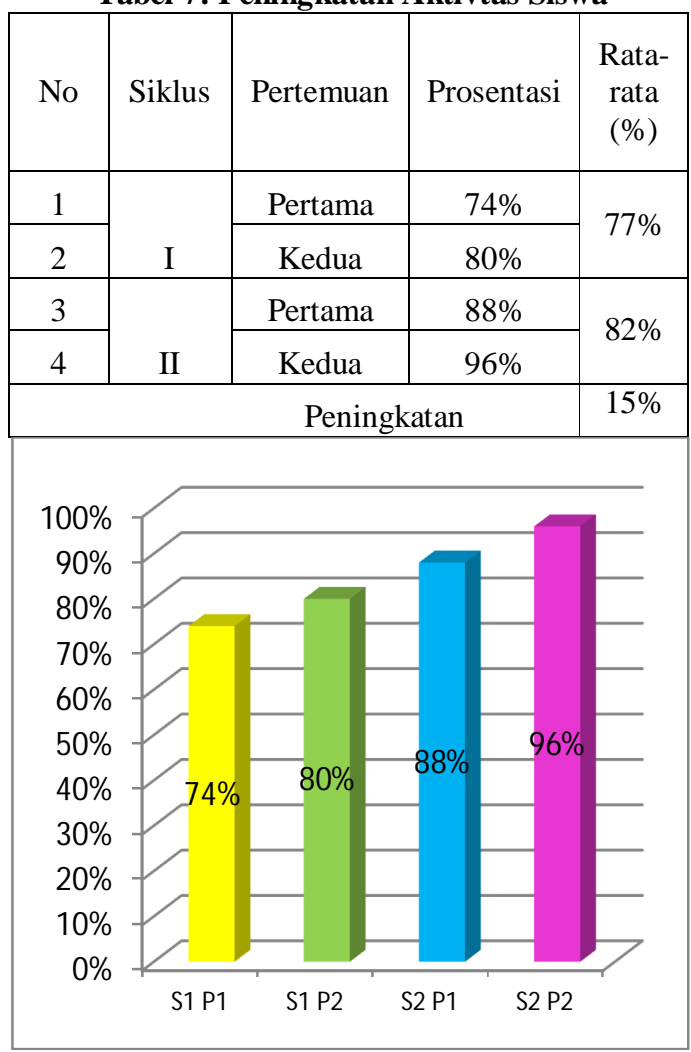

Secara umum penelitian tindakan kelas yang dilakukan untuk meningkatkan hasil belajar pada pembelajaran matematika di kelas IV SDN 04 Koto
Gadang Kecamatan Padang Ganting Kabupaten Tanah Datar. Dimana terjadi peningkatan pada seluruh aspek yang di amati dan di nilai. Berdasarkan data diatas maka penelitian tindakan kelas ini sudah berhasil karena suda berada diatas indiktor keberhasilan yang telah ditetapkan yaitu $>85 \%$.

\section{SIMPULAN DAN SARAN Simpulan}

Berdasarkan pembahasan di atas diambil simpulan sebagai berikut:

1. Pembelajaran melalui kooperatif tipe Numbered Heads Together (NHT) dapat meningkatkan hasil belajar matematika pada materi menentukan operasi perkalian di kelas IV SDN 04 Koto Gadang Kecamatan Padang Ganting Kabupaten Tanah Datar. Hal ini dibuktikan ketuntsan siswa pada siklus I dari tes kognitif $71 \%$ setelah di refleksi meningktan pada siklus II menjadi $89 \%$ terjadi peningkatan sebesar $18 \%$.

2. Aktivitas guru dalam kegiatan pembelajaran melalui kooperatif tipe Numbered Heads Together (NHT) dapat meningkatkan hasil belajar matematika pada materi menentukan operasi perkalian di kelas IV SDN 04 Koto Gadang Kecamatan Padang Ganting Kabupaten Tanah Datar sangat baik dan meningkat, terbukti aktivitas guru siklus I $74 \%$ terlaksana, setelah direfleksi meningkat pada siklus II menjadi 93\% terjadi peningkatan $19 \%$.

3. Aktivitas siswa dalam kegiatan pembelajaran kooperatif tipe Numbered Heads Together (NHT) dapat meningkatkan hasil belajar matematika pada materi menentukan operasi perkalian di kelas IV SDN Jawa Laut 2 Martapura sangat baik dan meningkat, terbukti aktivitas siswa siklus I $77 \%$ terlaksana, setelah 
direfleksi meningkat pada siklus II menjadi $92 \%$ terjadi peningkatan $15 \%$.

Saran

Berdasarkan hasil penelitian ini dapat disarankan:

1. Guru dapat menggunakan metode pembelajaran yang relevan dengan materi yang diajar salah satunya dengan menggunakan kooperatif tipe Numbered Heads Together (NHT) sangat cocok untuk memngembangkan kemampuan siswa berpikir.

2. Kepala sekolah disarankan menjadikan PTK ini acuan dan referensi bagi sekolah lain dalam mengembangkan kompetensi profesional di bidang karya ilmiah.

\section{DAFTAR PUSTAKA}

Ade Rusliana. 2007. Konsep Dasar Evaluasi Hasil Belajar. Jakarta. Bumi Aksara

BSNP. 2006. Panduan Penyusunan Kurikulum Tingkat Satuan Pendidikan Jenjang Pendidikan Sekolah dasar. Jakarta: BSNP

Depdiknas. 2006. Kurikulum Tingkat Satuan Pendidikan: Jakarta.

Em Zul Fajri dan Ratu Aprilia Senja. (2004). Kamus lengkap bahasa Indonesia. Jakarta: Difa Publiser.

Erman Suherman dkk. 2001. Strategi Pembelajaran Matematika Kontemporer. Bandung: FMIPA UPI

Heruman.2008.Model pembelajaran Matematika Di Sekolah Dasar.Bandung; PT Remaja Rosda Karya

Karso, dkk. 2007. Pendidikan Matematika I. Jakarta: Depdikbud
Lie, Anita. 2008. Cooperative Learning. Jakarta : Gramedia

Nana Sudjana. 2005. Penilaian Hasil Proses Belajar Mengajar. Bandung: Rosa Karya

............. 2010. Penilaian Hasil Proses Belajar Mengajar. Bandung: Remaja Rosdakarya

Rahmi, 2008. Model Pembelajaran Kooperatif Tipe Number Head Together (NHT) Sebagai Upaya Untuk Meningkatkan Pemahaman Siswa Dalam Matematika. Jurnal PTK Percikan: Vol. 89 Edisi Juni 2008

Permendiknas No. 21 Tahun 2007 tentang Standar Isi Untuk Satuan Pendidikan Dasar dan Menengah

Prihandoko, Antonius Cahya. 2006. Memahami Konsep Matematika Secara Benar Dan Menyajikannya Dengan Menarik. Departemen Pendidikan Nasional. Jakarta

S.Eko Putro Widoyoko. 2009. Evaluasi Program Pembelajaran. Yogyakarta ; Pustaka Belajar.

Sutratina, Tirtonegoro.2001. Penelitian Hasil belajar mengajar.Surabaya: Usaha Nasional

Suharjo.2006.Mengenal Pendidikan Sekolah dasar.Jakarta: Departemen Pendidikan Nasional Direktorat Jenderal Pendidikan Tinggi Direktorat ketenagaan.

Sukajati, 2008. Penelitian Tindakan kelas di Sekolah Dasar.Yogyakarta: Depdiknas 